\title{
RESOLUSI KONFLIK DALAM PENDIRIAN RUMAH IBADAH GEREKA BETHEL INDONESIA DI KELURAHAN KEBONLEGA KECAMATAN BOJONGLOA KIDUL KOTA BANDUNG
}

\author{
Azka Fatina Bakti \\ Prodi Ilmu Pemerintahan, Fakultas Ilmu Sosial dan Ilmu Politik, \\ Universitas Jenderal Achmad Yani Cimahi - Bandung
}

\begin{abstract}
Abstrak
Wilayah Jawa Barat konflik keagamaan yang berlatar belakang pendirian rumah ibadat banyak terjadi. Pembangunan tempat ibadat, khususnya gereja sering memicu konflik dengan masyarakat di sekitar lokasi pendirian rumah ibadat tersebut. Konflik ini terjadi umumnya karena gereja didirikan di tengah-tengah pemukiman yang mayoritas penduduknya Muslim. Dengan identifikasi masalah Bagaimana proses resolusi konfik dalam pendirian Gereja Bethel Indonesia di Kelurahan Kebonlega. Dalam penelitian ini menggunakan metode peneltian deskripstif dengan pendekatan kualitatif. Hasil dari peneliti ini adalah resolusi konflik dalam Pendirian Rumah Ibadah Gereja Bethel Indonesia di Kelurahan Kebonlega Kecamatan Bojongloa Kidul Kota Bandung sudah optimal inidaksinya bahwa konflik yang telah ditangani melaui pengawasan ditempat konflik yang rutin saling berkoordinasi untuk menjaga situasi yang kondusif, melaui musyawarah dan negosiasi menghasilkan solusi dengan hasil masyarakat sepakat dengan pendirian rumah ibadah dan Panitia Gereja memberikan bantuan berupa CSR untuk masyarakat, dengan demikian sudah terjalin kerjasama di masyarakat dan diharapkan dapat tetap dalam keadaan damai jangka panjang.
\end{abstract}

Kata kunci: resolusi konflik, Rumah Ibadah, Masyarakat.

\begin{abstract}
In West Java, there have been many religious conflicts with the background of the construction of houses of worship. The construction of places of worship, especially churches, often triggers conflicts with the communities around the location where the houses of worship are built. This conflict occurred mainly because the church was established in the middle of a predominantly Muslim settlement. By identifying the problem. How is the conflict resolution process in the establishment of the Indonesian Bethel Church in Kebonlega Village? This study using descriptive research methods with a qualitative approach. The result of this research is that the conflict resolution in the establishment of Indonesian Bethel Church Houses of Worship in Kebonlega Subdistrict, Bojongloa Kidul District, Bandung City is optimal. The perception is that conflicts that have been handled through surveillance in conflict areas routinely coordinate with each other to maintain a conducive situation, through deliberations and negotiations to produce solutions. with the result that the community agreed with the establishment of houses of worship and the Church Committee assisted in the form of CSR for the community, thus cooperation had been established in the community and it was hoped that it could remain in a state of longterm peace.
\end{abstract}




\section{Keywords: conflict resolution, houses of worship, society.}

\section{PENDAHULUAN}

Konflik merupakan salah satu esensi dari kehidupan dan perkembangan manusia yang memiliki karakteristik yang beragam. Menurut Wirawan (2013:5) Konflik adalah proses ketergantunggan yang diekspresikan di antara dua pihak atau lebih yang saling tergantung mengenai objek konflik, menggunakan pola prilaku dan interkasi konflik yang menghasilkan keluaran konflik. Dari definisi ada jumlah indikator yang membentuk konflik, yaitu proses, dua pihak, atau lebih, saling tergantung, pertentangan mengenai objek konflik, diekspresikan, pola perilaku, interaksi kinflik, dan keluaran konflik. Menurut Raho (2007:72) konflik adalah kenyataan hidup (reality) yang tidak terhindarkan (undeniable) dan bersifat kreatif. Akar konflik bermula dari adanya perbedaan, sedangkan perbedaan adalah kenyataan yang dihadapi setiap manusia. Perbedaan dapat bersifat alamiah dan bisa pula nonalamiah (perolehan).

Manajemen konflik di Indonesia dilaksanakan secara sistematis dan terencana dalam situasi dan peristiwa baik sebelum, pada saat, maupun sesudah terjadi konflik yang mencakup pencegahan konflik, penghentian konflik, dan pemulihan pasca konflik. Pemulihan pasca konflik merupakan istilah pemerintah Indonesia untuk kegiatan resolusi konflik. Resolusi konflik atau penyelesaian konflik seringkali terlupakan dan gagal dilaksanakan yang menyebabkan suatu konflik tidak terselesaikan dan memunculkan konflik baru. Dalam rangka mencapai penyelesaian konflik yang damai maka diperlukan keterlibatan bukan hanya pihak-pihak yang berkonflik tetapi juga pemerintah dan masyarakat.

Dalam beberapa tahun terakhir kasus konflik berlatar belakang pendirian rumah ibadat terus terjadi. Meski demikian, pada banyak kasus juga banyak rumah ibadat dapat berdiri dan diterima warga sekitar tanpa menimbulkan konflik. Menurut Jamaludin (2015:167) bahwa "pada satu sisi rumah ibadah yang berbeda agama dapat saling berdampingan (harmoni), tetapi pada sisi lain keberadaan rumah ibadah masih mengundang kontroversi sehingga sering menimbulkan konflik antarumat beragama”. 
Pendirian rumah ibadat pada umumnya dibangun di tempat yang strategis agar mudah diakses oleh para jemaah. Wilayah ini menuntut adanya penyesuaian dengan tata aturan yang diberlakukan oleh masyarakat. Namun karena pendirian rumah ibadat berkenaan dengan agama atau keyakinan individu tertentu dan agama termasuk dalam stratifikasi sosial, maka penyesuaiannya pun bergantung pada kesepakatan bersama. Jika agama termasuk pada stratifikasi sosial di wilayah tertentu, pihak yang sangat diuntungkan adalah umat yang mayoritas, sedangkan yang minoritas cenderung memerlukan ekstra penyesuaian. Pendirian rumah ibadah pada wilayah publik terkadang menimbulkan persoalan dan terkadang tidak pada wilayah lainnya. Persoalan yang dimaksud dapat mencitrakan kerukunan umat beragama pada wilayah tersebut.

Untuk wilayah Jawa Barat konflik keagamaan yang berlatar belakang pendirian rumah ibadat banyak terjadi. Pembangunan tempat ibadat, khususnya gereja sering memicu konflik dengan masyarakat di sekitar lokasi pendirian rumah ibadat tersebut. Konflik ini terjadi umumnya karena gereja didirikan di tengah-tengah pemukiman yang mayoritas penduduknya Muslim. Dalam data yang terdokumentasikan pada tahun 2010, persoalan konflik rumah ibadat mengarah pada kelompok-kelompok tertentu: Jemaat Kristiani, Ahmadiyah, dan berbagai paham serta pandangan keagamaan yang dianggap sesat.

Pada tahun 2010, Setara Institute mencatat 59 tempat ibadah yang mengalami gangguan dalam berbagai bentuknya: penyerangan, penyegelan, penolakan, larangan aktivitas ibadah, dan lain-lain. Dari 59 tempat ibadah tersebut, mayoritas menimpa jemaat Kristiani (43 tempat ibadah), Ahmadiyah (9 tempat ibadah), umat Islam (2 tempat ibadah), LDII (2 tempat ibadah), umat Buddha (2 tempat ibadah), dan Wahabi (1 tempat ibadah). Data tersebut menggambarkan bahwa pendirian rumah ibadat merupakan potensi konflik. Dari data itu juga dapat disimpulkan fakta lain yaitu bahwa pertumbuhan pembangunan rumah ibadat (gereja) di wilayah Jawa Barat terus mengalami kenaikan.

Pemerintah Kota Bandung sampai saat ini telah menerbitkan dua izin gereja yang sebelumnya dipermasalahkan, di mana Bapak Wali Kota Bandung 
menjamin tidak akan mencabut izin meski ada desakan dari sebagian warga karena Pemerintah Kota Bandung telah berkomitmen menjadikan Kota Bandung sebagai Kota Ramah HAM, di mana setiap kelurahan diwajibkan membuat laporan tentang pemenuhan HAM di wilayah masing-masing. Menurut Pak Kepala Badan Kesatuan Bangsa dan Politik Kota Bandung Hikmat Ginanjar pada tahun 2016, Pemerintah Kota Bandung telah menerbitkan 3 kebijakan yang memperkuat perlindungan hak atas dasar kebebasan beragama dan berkeyakinan, di antaranya:

1. Terbitnya Surat Edaran Wali Kota Bandung tertanggal 12 Juli 2016 tentang larangan menyampaikan pendapat di muka umum (unjuk rasa), demonstrasi di sekitar tempat ibadah;

2. Terbitnya Surat Edaran Wali Kota Bandung tertanggal 7 Desember 2016 tentang penggunaan gedung pertemuan untuk kegiatan keagamaan yang bersifat insidental;

3. Terbitnya Surat Edaran Wali Kota Bandung tertanggal 7 Desember 2016 tentang jaminan melaksanakan ibadah sesuai dengan keyakinan.

Dalam proses Kota Bandung menjadi Kota Ramah HAM, masih ada terjadi suatu konflik yang muncul dikarenakan Wali Kota Bandung mengeluarkan izin gereja. Seperti yang tersjadi salah satu sumber konflik muncul pada masyarakat yang menolak dan merasa keberatan dengan pemdirian rumah ibadah Gereja Bethel Indonesia di Kelurahan Kebonlega Kecamatan Bojongloa Kidul Kota Bandung.

Sejarah pembangunan Gereja Bethel Indonesia sebelumnya merupakan tanah kosong dan dibeli oleh pihak panitia Gereja untuk dibangun Gereja Bethel Indonesia yang baru yang berada di Jl. Kopo 445 Kelurahan Kebonlega Kota Bandung. Pada tahun 2012 pihak Gereja memberikan surat permohonan kepada Ketua RW 09 untuk penunjang syarat pembangunan Rumah Ibadah yang di atur dalam Peraturan Bersama Menteri Agama dan Menteri Dalam Negeri Nomor 8 dan 9 Tahun 2006 Tentang Pedoman Pelaksanaan Tugas Kepala Daerah/Wakil Kepala Daerah dalam Pemeliharaan Kerukunan Umat Beragama, Pemberdayaan Forum 
Kerukunan Umat Beragama, dan Pendirian Rumah Ibadah Pasal 14 ayat (1) dan (2) yaitu:

(1) Pendirian Rumah Ibadah harus memenuhi persyaratan administratif da persyaratan teknis bangunan gedung.

(2) Selain memenuhi persyaratan sebagaimana dimaksud pada ayat (1) pendirian rumah ibadah harus memenuhi persyaratan khusus meliputi:

a. Daftar nama dan Kartu Tanda Penduduk pengguna rumah ibadat paling sedikit 90 (sembilan puluh) orang yang disahkan oleh pejabat setempat sesuai dengan tingkat batas wilayah sebagaimana dimaksud dalam Pasal 13 ayat (3);

b. Dukungan masyarakat setempat paling sedikit 60 (enam puluh) orang yang disahkan oleh lurah/kepala desa;

c. Rekomendasi tertulis kepala kantor departemen agama kabupaten/kota; dan

d. Rekomendasi tertulis FKUB kabupaten/kota.

Namun warga mempertanyakan dan menolak karena Gereja di bangun tepat di dekat psantren. Penolakan masyarakat ditandai dengan aksi yang dilakukan sekitar 1000 santri, orangtua santri, Nahdliyyin Centre, Forum Silahturahmi Pondok Pesantren (Fosil PP) se-Kota Bandung, dan Muslimat NU Bandung serta pimpinan Pondok Pesantren Sirnamiskin melakukan aksi unjuk rasa di halaman kantor Biz Park, Jl. Kopo, Kelurahan Kebonlega, Kecamatan Bojongloa Kidul. Direktur Nahdiiyyin Centre, Abdul Chalik menuturkan aksi itu dipicu adanya rencana pembangunan rumah ibadah di samping lokasi pondok pesantren. Pihaknya kedatangan perwakilan dari Gereja Bethel Indonesia (GBI) yang memberi tahu akan membangun rumah ibadah di lokasi pembangunan Biz Park yang berdekatan dengan pondok pesantren.

Pada 30 Oktober 2017 Gereja Bethel Indonesia sudah disahkan oleh Pemerintah mengenai legalitas IMB rumah ibadah. Pihak panitia membangun Gereja yang lokasinya berbeda pada saat tahun 2012, GBI yang dibangun ini beralamat di J1. Karasak Barat Kelurahan Kebonlega Kecamatan Bojongloa Kidul yang berarti secara administrasi pihak panitia Gereja sudah memenuhi prosedur 
yang diatur dalam Peraturan Bersama Menteri Agama dan Menteri Dalam Negeri Nomor 8 dan Nomor 9 Tahun 2006 tentang Pedoman Pelaksanaan Tugas Kepala Daerah/Wakil Kepala Daerah dalam Pemeliharaan Kerukunan Umat Beragama, Pemberdayaan Forum Kerukunan Umat Beragama (FKUB), dan Pendirian Rumah Ibadah. Namun dengan dikeluarkannya IMB Gereja, pihak panitia mendapat penolakan dari warga. Pemerintah Kota Bandung telah menerbitkan 3 kebijakan yang memperkuat perlindungan hak atas dasar kebebasan beragama dan berkeyakinan yang salah satunya adalah Terbitnya Surat Edaran Wali Kota Bandung tertanggal 12 Juli 2016 tentang larangan menyampaikan pendapat di muka umum (unjuk rasa), demonstrasi di sekitar tempat ibadah. Yang berarti pemerintah telah mengeluarkan kebijakan tersebut sebagai salah satu upaya meresolusi konflik mengenai perizinan pembangunan rumah Ibadah, masih terjadi penolakan yang mengakibatkan konflik terjadi.

\section{METODE PENELITIAN}

Dalam penelitian ini peneliti menggunakan metode kualitatif dengan menggunakan pendekatan deskriptif. Moleong (2007:6) penelitian kualitatif adalah penelitian yang bermaksud untuk memahami fenomena tentang apa yang dialami oleh subjek penelitian misalnya prilaku, persepsi, motivasi, tindakan dan lain-lain secara holistik, dan dengan cara deskripsi dalam bentuk kata-kata dan bahasa, pada suatu konteks khusus yang alamiah dan dengan memanfaatkan berbagai metode ilmiah.

\section{PEMBAHASAN}

Resolusi konflik atau penyelesaian konflik dapat diartikan sebagai sebuah proses untuk mencapai keluaran konflik yang diinginkan dengan menggunakan metode langkah kerja tertentu sebagai upaya menangani sebab-sebab konflik dan berusaha membangun hubungan baru yang bisa bertahan lama diantara kelompok- kelompok yang bermusuhan. Metode yang dimaksud adalah Win\&win solution. Akan tetapi konflik di kawasan pembangunan Gereja Bethel Indonesia di Kelurahan Kebonlega yang dimulai pada tahun 2012 hingga saat ini masih belum sepenuhnya mencapai titik damai. Ditandai dengan aksi unjuk rasa masyarakat kelurahan Kebonlega dalam pendirian Gereja. 
Alasan masyarakat menolak dikarenakan pada saat itu panitia GBI ingin membangun Gereja yang berdekatan dengan pesantren sehingga adanya pembatalan pembangunan tersebut. Pada tahun 2017 pihak panitia Gereja sudah mengantongi surat izin pendirian rumah ibadah yang sudah disahkan oleh Walikota Bandung Bapak Ridwan Kamil. Namun masyarakat kembali menolak atas pendirian Gereja. Masyarakat ingin peninjauan kembali pada izin pendirian Gereja, masyarakat khawatir dengan isu kristenisasi dan karena sudah ada Gereja yang sama yang dibangun dekat wilayah pembangunan Gereja yang baru. Proses resolusi konflik inilah yang menjadi fokus penelitian ini guna mengetahui bagaimana resolusi konflik dalam Pendirian rumah ibadah Gereja Bethel Indonesia di Keluharan Kebonlega Kecamatan Bojongloa Kidul Kota Bandung.

\section{Peacekeeping}

\section{a. Melakukan Pengawasan di Tempat Konflik}

Peacekeeping atau menjaga keadaan damai, berhubungan dengan upaya menghentikan atau mengurangi aksi kekerasan antara kedua belah pihak yang berkonflik. Dalam implementasi kegiatan resolusi konflik sangatlah penting untuk melakukan pengawasan di tempat terjadinya konflik untuk mengurangi korban konflik. Pengawasan tentu saja tidak dilakukan oleh sembarang orang atau kelompok, tetapi dilakukan oleh lembaga atau kelompok yang diberi kewenangan dan mandat untuk melakukan pengawasan di kawasan Kelurahan Kebonlega Kecamatan Bojongloa Kidul Kota Bandung Berdasarkan wawancara peneliti dengan Kepala Bidang Kewaspadaan Nasional Badan Kesatuan Bangsa dan Politik Kota Bandung, informan mengemukakan bahwa:

"Dalam proses penanganan konflik dengan melakukan pengawasan saat terjadi konflik tentu diawasi langsung oleh kami dari Bidang Kewaspadaan Nasional Bakesbangpol Kota Bandung bekerjasama dengan Polsek Bojongloa Kidul, Babinkantibmas, Lurah Kebonlega, dan Pengurus RW setempat. Dengan tujuan mencegah indikasi tindak kekerasan yang bila muncul dari masyarakat yang melakukan penolakan dengan adanya pendirian Gereja. Sampai saati ini situasi wilayah tersebut sudah kembali kondusif namun kami tetap melakukan monitoring di Kelurahan Kebonlega."

Kemudian keterangan tidak jauh berbeda berdasarkan wawancara peneliti dengan Lurah Kebonlega Kecamatan Bojongloa Kidul Kota Bandung, informan mengatakan bahwa: 
"Saat konflik itu terjadi dan saat konflik sudah terselesaikan pengawasan tetap dilakukan terutama di wilayah RW 09. Dengan bekerja sama dengan Babinkamtibmas, Polsek Bojongloa Kidul, dan dengan pihak Pemerintah Kota Bandung (Bidang Kewaspadaan Nasional Bakesbangpol Kota Bandung). Dan dari pihak Pemerintah Kota Bandung selalu melakukan monitoring rutin mengenai perkembangan wilayah konflik. Namun situasi sudah kembali kondusif dan sudah tidak ada aksi unjuk rasa dan aksi yang berindikasi kekerasan."

Untuk membandingkan keterangan dari pihak pemerintah di atas, peneliti pun mengambil keterangan dari masyarakat sekitar dengan berdasarkan wawancara peneliti dengan Sekretaris RW 09, pada tanggal 26 Februari 2018, informan mengemukakan bahwa

"Betul adanya pengawasan disekitar pembangunan rumah ibadah. Dari kelurahan Kebonlega, Pemerintah Kota Bandung, Babinkamtibmas, dan Polsek Bojongloa Kidul sempat melalukan pengawasan secara rutin di wilayah ini. Karena pada saat konflik itu terjadi berbagai penolakan dilakukan dengan melakukan aksi dan penempelan pamflet dimana-mana. Namun kami dari pengurus RW 09 terus melalukan ronda (pengawasan) disekitar wilayah kami agar tidak ada lagi pamflet yang mengindikasikan penolakan. Karena kasus ini juga sudah terselesaikan."

Peneliti melihat bahwa dalam proses pengawasan di tempat konflik dalam konflik pendirian rumah ibadah di Kelurahan Kebonlega telah dilakukan oleh Pemerintah Kota Bandung, Polsek Bojongloa Kidul, Babinkamtibmas, Lurah Kebonlega, dan pengurus RW 09 selama konflik itu sedang berlangsung hingga konflik sudah selesai. Berdasarkan data yang peneliti dapatkan selama di lapangan bahwa konflik terjadi saat pendirian rumah ibadah Gereja Bethel Indonesia yang akan dibangun di Kelurahan Kebonlega. Pembangunan Gereja baru ini mendapat penolakan dari masyarakat dengan beberapa alasan yaitu, masyarakat ingin peninjauan kembali perizinan bangunan yang dimiliki panitia Gereja karena dirasa tidak memenuhi syarat, takut jika adanya krsitenisasi, Konflik tersebut terus berlanjut namun dengan pengawasan dan peran dari Pemerintah Daerah Kota Bandung dengan Kelurahan Kebonlega dalam meredam konflik untuk mengurangi korban konflik sudah berjalan optimal. Terlihat dari situasi dan kondisi di Kelurahan Kebonlegta terutama di RW 09 yang sudah kondusif sesuai dengan keterangan yang diuraikan ketiga informan. Tidak ditemukannya aksi penolakan, pamflet, dan lainnya yang mengindikasikan penolakan dalam pendirian Gereja. 
Pengawasan menjadi langkah pertama dalam suatu resolusi konflik mengatasi konflik. Hal ini dilakukan untuk mengetahui apa penyebab konflik itu terjadi dan menentukan cara agar konflik terselesaikan. Pengawasan merupakan cara yang penting termasuk dalam resolusi konflik dan sesuai dalam UndangUndang Nomor 7 Tahun 2012 Tentang Penanganan Konflik Sosial Pasal 3 bahwa pengawasan yang dilakukan dalam upaya penangan konflik berujuan untuk "menciptakan kehidupan masyarakat yang aman, tenteram, damai, dan sejahtera".

Pengawasan ditempat konflik telah dilaksanakan dengan optimal yang diantaranya saling berkoordinasi antar intansi yaitu, Pemerintah Kota Bandung, Kelurahan, Polsek Bojongloa Kidul, Babinkamtibmas, dan pengurus RW 09 sehingga konflik dapat segera ditangani dan tidak adanya tindak kekerasan yang dilakukan oleh masyarakat kepada pihak panitia pambangunan Gereja walaupun sempat ada pemasangan pamflet yang menandakan masyrakat keberatan dengan pendirian Gereja Bethel Indonesia di Kelurahan Kebonlega. Namun dengan pengawasan yang dilaksanakan secara rutin dengan kegiatan monitoring oleh Kepada Bidang Kewaspadaan Nasional Kepala Badan Kesatuan Bangsa dan Politik Kota Bandung serta peran RW 09 hal tersebut dapat segera teratasi sehingga situasi di Kelurahan Kebonlega tetap kondusif dan tidak ada unsur provokasi yang tersebar dalam masyarakat.

\section{b. Adanya keterlibatan Aparat Penegak Hukum}

Keterlibatan penegak hukum menjadi salah satu ciri upaya menjaga keadaan damai karena penegak hukum khususnya kepolisian dianggap penegak perdamian yang netral, tidak memihak kepada salah satu atau kedua belah pihak yang berkonflik. Pada Undang-Undang Nomor 7 Tahun 2012 Tentang Penangan Konflik Sosial, Polisi memiliki posisi sentral dalam penanganan konflik. Ditegaskan "Polri adalah alat Negara yang berfungsi sebagai pemeliharaan kemanaan dan ketertiban masyarakat, penegakan hukum, perlindungan, pengayoman, dan pelayanan kepada masyrakat”. Tetapi Polri bukanlah aktor utama dalam proses resolusi koflik karena actor utama dalam resolusi konflik adalah pemerintah sutau penentu kebijakan dalam penanganan konflik. Berasarkan wawancara peneliti dengan Kepala Bidang Kewaspadaan Nasioanal Bakesbangpol Kota Bandung, informan mengemukakan bahwa 
"Keterlibatan dalam pengawasan di tempat konflik tentu saja dilakukan oleh Polsek Bojongloa Kidul dan Babinkamtibmas agar tidak adanya tindak kekerasan yang terjadi. Namun dengan keterlibatan Polsek Bojongloa Kidul keadaan tempat konflik tetap aman. Polsek Bojongloa Kidul melakukan pengawasan sekaligus invetigasi mengenai penyebab konflik dan mengapa konflik terjadi."

\section{Berdasarkan wawancara peneliti dengan Lurah Kebonlega Kecamatan}

Bojongloa Kidul Kota Bandung , informan mengemukakan bahwa

"Keterlibatan pengeak hukum pada saat konflik yaitu Polsek Bojongloa Kidul yang bekerjasama dengan Babinkamtibmas. Karena tugasnya polisi untuk mengamankan tentu kami berkerjasama dengan Polsek Bojongloa Kidul agar konflik yang terjadi tidak merusak fasilitas umum dan tidak adanya tindak kekerasan. Apabila ditemukan tindak kekerasan dan merusak fasilitas umum akan ditindak langsng oleh pihak polisi."

Keterangan yang tidak berbeda saat peneliti wawancara dengan Sekretris informan mengemukaan bahwa

"Keterlibatan penegak hukum dalam penanganan konflik sangat terlibat, bukan ha nya melakukan pengamanan saat konflik terjadu namun ikut bersama-sama mencari solusi dalam penyelesaian konflik ini. Peran dari penegak hukum tersebut banyak membantu kami."

Keterlibatan penegak hukum atau aparat kepolisian dalam melakukan pengawasan di tempat terjadinya konflik telah dilakukan secara rutin yang berkoordinasi dengan Pemerintah Daerah, Babinkamtibams, Kelurahan Kebonlega, dan pengurus RW 09. Sehingga terciptalah situasi yang aman dan kondusif yang ditandai dengan tidak adanya aksi penolakan yang merugikan pihak Gereja. Keterlibatan penegak hukum yang sangat penting karena menjadi pihak yang tidak memihak (netral) dan dipercaya dalam mengajukan bahan untuk solusi untuk penyelesaian konflik.

\section{c. Pemulihan Kondisi Keamanan dan Ketertiban}

Tejadinya konflik di suatu tempat merupakan bukti dari kurangnya keamanan dan ketertiban di tempat tersebut. Keamanan berhubungan dengan terjaminnya hak dan kewajiban, sedangkan ketertiban berhubungan dengan kesesuaian dengan nilai norma dan hukum yang berlaku. Dengan demikian terjadinya konflik dapat diakbatkan oleh kurangnya terjamin hak dan kewajiban serta ketidak sesuaian atau pelanggaran nilai, norma dan hukum yang berlaku. Pada kasus pendirian Gereja di Kelurahan Kebonlega dapat diartikan bahwa yang 
menjadi faktor tejadinya konflik adalah ketidak terpenenuhinya masyarakat untuk mendapatkan informasi atau sosialisasi mengenai pendirian Gereja dari pihak Gereja kepada masyarakat Kelurahan Kebonlega. Oleh karena itu masyrakat menuntut pemerintah karena kekhawatiran masyarakat dalam pembangunan Gereja yang berdekatan dengan pesantren di Kelurahan Kebonlega, dan masyrakat menganggap bahwa pihak Gereja melakukan pelanggran aturan. Dengan demikian pemulihan kondisi keamanan dan ketertiban sangat diperlukan agar kondisi damai dan terjaga.

Menurut hasil wawancara dengan Kepala Bidang Kewaspadaan Nasional Bakesbangpol Kota Bandung, informan mengemukakan bahwa

"Upaya pemulihan ketertiban pasckonflik melalui monitoring dari Pemerintah Daerah khususnya Bidang Kewaspadaan Nasional dan check lokasi pembangunan Gereja. Monitorig dilakukan setiap minggu pada saat setelah konflik terjadi. Untuk melihat setiap perkembangan situasi wilayah yang akan langsung dilaporkan kepada Walikota. Tujuan monitoring yaitu bentuk pengawasan dari Bidang Kewaspadaan Nasional agar konflik tidak terjadi kembali dan menyebabkan keresahan di dalam masyayrakat. Monitoring dilakukan berkoordinasi dengan FKUB Bojongloa Kidul, dan Kelurahan Kebonlega."

Kemudian hal serupa dikemukakan oleh Lurah Kebonlega terkait upaya pemulihan kondisi keamanaan dan ketertiban pada saat konflik beliau mengemukakan:

"Setelah konflik itu terjadi, upaya pemulihan kondisi ketertiban dan keamanan dilakukan oleh kelurahan dengan cara pendekatan kepada masyarakat yang menolak dengan mencari tahu alasan mereka masih menolak pendiran rumah ibadah. Dan cara lain yaitu dengan membentuk tim verifikasi untuk memverifikasi dokumen persyaratan pendirian Gereja dari pihak Panitia. Seperti dokumen persetujuan warga RW 09 yang lengkapi dengan tandatangan dan fotocopy KTP yang satu persatu mendatangi warga RW 09 dan ditanya mengenai pendirian Gereja sesuai yang tertera dalam dokumen persetujuan warga RW 09. Ini dilakukan karena Lurah ingin mengetahui secara langsung apakah dokumen yang dikumpulkan oleh Panitia sudah sesuai sesuai dengan PMB Nomor 8 dan 9 tentang Pendirian Rumah Ibadah, untuk sealnjutnya dapat direkomendasikan ke tingkat Kecamatan. Dengan bukti berupa video yang Lurah dokumentasikan. Dan ternyata terindikasi empat orang yang masih menolak dengan pendirian rumah ibadah."

Upaya pemulihan kondisi ketertiban dan keamanan dari konflik yang dilakukan oleh Pemerintah Kota Bandung, Kelurahan Kebonlega, dan pengurus RW 09 dengan melakukan pengawasan dan pendekatan kepada masyarakat yang masih 
menolak pendirian Gereja. Pendekatan dilakukan agar mengetahui penyebab penolakan dan penolakan dilakukan kurang lebih oleh empat orang yang sangat tidak ingin Gereja tersebut didirikan dengan alasan takut adanya penyebaran agama Kristen (kristenisasi) pada masyarakat. Namun mayoritas mayarakat sudah menandatangi pesetujuan pendirian Gereja di RW 09 dengan bukti surat persetujuan Warga RW 09, yang dilengkapi dengan tanda tangan dan fotokopi KTP yang telah sahkan/dilegalisir oleh Kecamatan Bojongloa Kidul Kota Bandung berjumlah 232 orang. Dan setelah dilakukan pengecekan langsung oleh Lurah Kebonlega dan pengurus RW 09 atas dokumen tersebut tidak ditemukannya pemalsuan tanda tangan atau fotokopi KTP yang telah kadaluarsa. Tuduhan antara yang diberikan masyarakat kepada panitia pembangunan Gereja tidak dapat dibuktikan dengn bukti fisik karena bukti tersbebuut sudah sangat jelas bahwa mayoritas masyrakat mendukung penuh pembangunan Gereja. Hal ini terbukti bahwa upaya yang dilakukan Pemerintah Daerah, Kelurahan Kebonlega, dan pengurus RW 09 sudah menjadikan situasi aman dan tertib dan pendirian Gereja bisa dilanjutkan.

\section{Peacemaking}

\section{a. Melakukan Musyawarah dan Negosiasi}

Peacemaking berkenaan dengan proses mempertemukan atau merekonsiliasi sikap politik dan strategi dari pihak-pihak bertikai. Proses tersebut dapat dilakukan negosiasi atau musyawarah antara pihak-pihak bertikai, juga dapat melibatkan pihak ketiga apabila kedua belah pihak merasa membutuhkannya dengan melakukan mediasi, arbitrasi, maupun dapat melalui lembaga peradilan negara. Syarat dari pihak ketiga adalah harus netral tidak memihak dan dapat persetujuan dari pihak-pihak yang bertikai. Pada proses peacemaking inilah arah tujuan dan keluaran dari resolusi konflik ditentukan apakah metode win\&win solution, win\&lose solution, atau kah avoiding (penghindaran). Hasil Wawancara peneliti dengan Lurah Kebonlega mengenai upaya musyawarah dan negosiasi dalam penyelesaian konflik pendirian Gereja, beliau mengemukakan:

"Musyawarah dan negosiasi difasilitasi oleh Kelurahan Kebonlega bertempat di Aula kantor Kelurahan Kebonlega sebanyak tiga kali dengan mempertemukan pihak masyarakat yang menolak dengan pihak panitia Gereja. Dipertemukan hingga tigakali dikarenakan pihak masyrakat tetap menolak dan tetap ingin adanya peninjauan ulang dan saat dimintai bukti tetang tuduhannya pihak tersebut tidak dapat memberikan bukti kuat. Secara adminitrasi sudah lengkap 
dan adminitrasi sesuai persyaratan PMB Nomor 8 dan 9 Tentang Pendirian Rumah Ibadah, maka hasilnya pendirian Gereja tetap dilakukan karena tidak ditemukan pelanggaran hukum."

Kemudian hal yang sama pada wawancara peneliti dengan Sekretaris RW 09 mengenai proses musyawarah dan negosiasi pada penolakan pendirian rumah ibadah, beliau mengemukakan:

"Musyawarah sudah difasillitasi oleh pengurus RW 09 dan Kelurahan Kebonlega, dengan sepakat bahwa pendirian rumah ibadah terus bisa berlanjut karna masyarakat yang menolak tidak dapat menunjukan bukti atas tuduhannya mengenai pelanggaran hukum yang dilakukan panitia Gereja. Akhirnya pembangunan Gereja bisa berjalan dengan aman."

Dan hasil wawancara peneliti dengan Panitia Pembanguna Gereja Bethel, informan mengemukakan:

"Pihak panitia mengikuti arahan Lurah Kebonlega untuk ikut dalam proses musyawarah dan negosiasi dengan masyarakat. Dan menemukan kata sepakat untuk tetap melanjutkan pembangunan. Dan pihak panitia Gereja sudah memenuhi syarat pendirian ruamh ibadah sesuai dengan PMB Nomor 8 dan 9 tentang Pendirian Rumah Ibadah."

Upaya musyawarah dan negosiasi dengan data akurat yang peneliti temukan dilapangan bahwa proses musyawarah dan negosiasi sudah menemukan win \& win solution dan sepakat pendirian rumah ibadah dilanjutkan sebagai semsetinya. Hal ini terbukti dengan hasil musyawarah dan negosiasi atau disebut sosialisasi yang difasilitasi Kelurahan Kebonlega adanya tanda tangan warga RW 09 yang tidak keberatan dengan rencana pendirian Gereja melalui berita acara Sosialisai RW 09. Dalam berita acara tersebut disebutkan bahwa warga RW 09 mendukung untuk pendirian sebuah Gereja di Kelurahan Kebonlega dengan catatan sebagai berikut:

1. Pihak pengurus gereja tidak menjalankan atau menyebarkan kristenisasi kepada Warga RW 09 dan sekitarnya.

2. Menjaga kerukunan umat beragama dan menjaga keamanan, ketertiban di Wilayah RW 09.

3. Tidak membuat sumur/galian/artesis/ melebihi kedalaman 100m lebih.

4. Memelihara jalan di Wilayah RW 09.

5. Bekerjasama sama dengan pengurus RW 09. 
Walaupun proses musyawarah tidak dilakukan hanya sekali lalu menemukan solusi, tapi akhirnya proses penyelesaian konflik dengan musyawarah dapat terlaksana dengan baik sehingga pembangunan Gereja Bethel Indonesia di Kelurahan Kebonlega dapat dilaksanakan tanpa perlu khawatir jika adanya timbul konflik kembali. Dengan hasil kesepakatan bahwa masyrakat akan merasa aman dan nyaman jika panitia pembangunan Gereja dapat menjamin tidak adanya penyebaran kristenisasi kepada masyarakat Kelurahan Kebonlega, dan bekerja sama dalam hal memelihara wilayah Kelurahan Kebonlega. Hal tersebut merupakan point penting yang diinginkan oleh masyarakat yang diwakili oleh RW

09. Bukan semata masyarakat anti toleran terdahap agama yang minoritas namun perlu adanya pendekatan yang dilakukan oleh panitia pembangunan Gereja bahwa akan ada pembangunan Gereja sehingga dapat terhindar dari konflik yang seperti ini.

\section{b. Adanya Intervensi Pihak Ketiga}

Pihak ketiga dalam resolusi konflik dimaksudkan kepada orang, kelompok, atau lembaga yang dipercaya oleh pihak-pihak yang berkonflik untuk turut membantu memberikan solusi atas permasalahan yang menyebabkan konflik. Keputusan hanya mengikat para pihak yang terlibat konflik sampai pihak ketiga tidak mempunyai wewenang untuk mengambil keputusan mengenai konflik. Pihak ketiga bisa berupa kembaga pemerintah, lembaga arbitrase yang dibentukan undang-undang, lembaga mediasi, atau pihak ketiga yang dibentuk berdasarkan kesepakatan pihak-pihak yang terlihat konflik. Menurut hasil wawnacara dengan Kepala Badan Kewaspadaan Nasioanl Bakesbangpol Kota Bandung, beliau mengemukakan:

"Dalam konflik terjadi perlu adanya keterlibatan pihak ketiga selain pihak yang sedang bertikai agar segera menemukan solusi. Dalam proses penyelesaian konflik ada keterlibatan dari pihak ketiga diantaranya Forum Kerukunan Umat Beragama (FKUB) Bojongloa Kidul sebagai organisasi kemasyarakatan yang berbasis pada pemuliaan nilai-nilai agama, FKUB memiliki peran dan fungsi yang sangat strategis dalam berperan serta membangun daerah masing-masing di tengah krisis multidimensional yang tengah terjadi yang berkoordinasi dengan Lurah Kebonlega, Polsek Bojonglo Kidul, Camat Bojongloa Kidul dalam proses sosialisasi permohonan pendiria Gereja." 
Intervensi pihak ketiga atau adanya keterlibatan pihak ketiga dalam penyelesaian konflik pendirian Gereja dibuktikan dengan adanya berita acara musyawarah yang bertempat di Aula Kecamatan Bojongloa Kidul yang dihadiri oleh Camat Bojongloa Kidul, Lurah Kebonlega, perwakilan KUA, perwakilan Polsek Bojongloa Kidul, dan Badan Kewaspadaan Nasioanal Bakesbangpol Kota Bandung dengan hasil musyawarah sebagai berikut :

1. Musyawarah mufakat untuk penyelesaian permasalahan pembangunan Gereja berdasarkan UUD dan Pancasila

2. Warga berharap adanya penempuhan tahapan sosialisasi rencana pembangunan Gereja terhadap warga masyarakat

3. Adanya cek lapangan oleh muspika tentang verifikasi data rencana pembangunan Gereja.

4. Pengumpulan bersama atau rapat bersama yang difasilitasi oleh kecamatan anatara pihak verifiaksi RW 09, tokoh agama, dan pihak-pihak yang keberatan.

5. Lurah akan mengundnag dan memverifikasi ke beberapa tokoh dan warga sesuai daftar tanda tangan persetujuan/dukungan

Peran pihak ketiga tidak bisa sepenuhnya bisa memutuskan namun hanya sebagai pemberi solusi dan berperan sebagai pihak yang netral atau tidak memihak. Dengan hasil kesepakatan yang tidak memberatkan salah satu pihak dan harus disetujui oleh dua pihak yang bertikai. Cara yang dilakukan dalam keterlibatan orang ketiga ini sebagai pihak penengah diantara pihak yang bertikai dengan mengundang seluruh masyarakat RW 09 Kelurahan Kebonlega dan pihak panitia pembangunan Gereja dalam kegiatan sosialisasi oleh Lurah Kebonlega dengan tujuan ingin ada keterbukaan dari masyarakat dan pihak panitia pembangun Gereja sehingga adanya kesepakatan damai dan menjalin kerjasama dalam jangka panjang.

\section{c. Pembuatan Peraturan Mengenai Objek Konflik}

Kebijakan dapat diartikan sebagai tujuan-tujuan, program-program, keputusan-keputusan, undang-undang, ketentuan-ketentuan, usulan-usulan dan rancangan-rancangan yang berisi strategi dan taktik untuk mencapai suatu tujuan. Hubungan kebijakan dan konflik adalah suatu kebijakan yang tidak tepat sasaran dan tidak dilaksanakan dengan baik maka akan menyebabkan konflik. 
Tetapi konflik juga dapat menjadi sumber pembuatan kebijakan baru karena pada dasarnya hasil dari upaya penangann konflik akan beupa keputusankeputusan, ketentuan-ketentuan, dan atau peraturan-peraturan mengenai sumber-sumber konflik tersebut. Dalam resolusi konflik rumah ibadah Gereja Bethel Indonesia di Kelurahan Kebonlega ini pemerintah yang memiliki kewenangan untuk membuat dan mengeluarkan kebijakan sebagai kewajibannya untuk menangani konflik.

Menurut hasil wawancara peneliti dengan Kepala Bidang Kewaspadaan Nasional Bakesbangpol Kota Bandung mengemukakan bahwa:

"Sebenarnya peraturan dalam pendirian rumah ibadah sudah ditentukan pertauran melalui SKB Peraturan Menteri dalam Negeri Agama Nomor 8 da Menteri Dalam Negeri Nomor 9 tahun 2006 Tentang Pendirian Rumah Ibadah. Dengan adanya peraturan tersebut sudah diatur jelas mengenai persyaratan pendirian rumah ibadah. Namun karena di Bandung sempat ada beberapa masalah dalam pendirian rumah ibadah, Pemerintah Kota Bandung telah menerbitkan 3 kebijakan yang memperkuat perlindungan hak atas dasar kebebasan beragama dan berkeyakinan, di antaranya:

1. Terbitnya Surat Edaran Wali Kota Bandung tertanggal 12 Juli 2016 tentang larangan menyampaikan pendapat di muka umum (unjuk rasa), demonstrasi di sekitar tempat ibadah;

2. Terbitnya Surat Edaran Wali Kota Bandung tertanggal 7 Desember 2016 tentang penggunaan gedung pertemuan untuk kegiatan keagamaan yang bersifat insidental;

3. Terbitnya Surat Edaran Wali Kota Bandung tertanggal 7 Desember 2016 tentang jaminan melaksanakan ibadah sesuai dengan keyakinan."

Dengan dibuatnya peraturan tersebut diharapkan masalah dalam antar umat Bergama terutama pada kasus pendirian rumah ibadah dapat terselesaikan. Pemerintah Daerah Kota Bandung sebagai Kota Ramah HAM sesuai dengan penghargaan yang diberikan oleh Komnas HAM bertujuan ingin membuat situasi aman dan nyaman bagi seluruh umat beragama dalam melakukan pembangunan rumah ibadah, beribadah, dan beragama sesuai dengan Pancasila sila ke satu bahwa "Ketuhanan Yang Maha Esa".

\section{Peacebulding}

a. Implementasi Peraturan Mengenai Objek Konflik

Setelah pembuatan keputusan atau peraturan sebagai upaya resolusi konflik, tentu saja keputusan dan peraturan tersebut harus dilaksanakan oleh semua pihak, terutama pihak-pihak yang terlibat dalam konflik. Pada implementasi kebijakan ini perlu memperoleh dukungan sumberdaya, dan penyusunan 
organisasi pelaksana kebijakan. Dalam upaya resolusi konflik rumah ibadah gereja bethel indonesia ini, pemerintah telah membuat dan memberlakukan peraturan-peraturan yang di harapkan dapat menyelesaikan atau meredam konflik yaitu keputusan Menteri bersama No 8 dan 9 Menteri Agama dan Menteri Dalam Negeri tentang Pedoman Pelaksanaan Tugas Kepala Daerah atau Wakil Kepala Daerah Dalam Pemeliharan Kerukunan Umat Beragama, Pemberdayaan Forum Umat Beragama dam Pendirian Rumah Ibadah di Kelurahan Kebonlega Kecamatan Bojongloa Kidul Kota Bandung. Hasil wawancara dengan Kepala Bidang Kewaspadaan Nasional Bakesbangpol Kota Bandung, beliau mengemukakan bahwa:

"Peraturan mengenai pendirian rumah ibadah sudah diatur. Dalam impelementasinya masih ada kasus penolakan yang terjadi di Bandung dalam pendirian Gereja. Kasusnya sama yaitu masyarakat ingin pemerintah mencabut izin pendirian ruamh ibadah. Ada yang hingga disarankan untuk di PTUN kan namun pihak yang keberatan tidak dapat memperlihatkan bukti berupa data. Ini menjadi pekerjaan Pemerintah Daerah dengan bagaimana cara tetap manjaga keurukunan antar umat beragama."

Hasil wawancara dengan Panitia Pembangunan Gereja Bethel Indonesia, beliau mengemukakan:

"Peraturan pendirian rumah ibadah sudah diatur dengan baik agar terjalinnya kerukunan antar umat Beragama. Peraturan diatur untuk seluruh umat agama di Indonesia. Sehingga tidak akan ada perpecahan agama di Indonesia. Bahwa kehidupan sosial hidup berdampingan. Sehingga tercipta hubungan toleransi antar umat beragama."

Impementasi kebijakan dalam pendirian rumah ibadah dari panitia pembangunan Gereja sudah menjalankan sesuai prosedur yang ada sehingga dapat langsung di rekomendasikan dan disahkan oleh Walikota Bandung. Kebijakan yang sudah di atur dalam PMB Nomor 8 dan 9 Tahun 2006 tentang Pedoman Pelaksanaan Tugas Kepala Daerah atau Wakil Kepala Daerah Dalam Pemeliharan Kerukunan Umat Beragama, Pemberdayaan Forum Umat Beragama dam Pendirian Rumah Ibadah bahwa Kepala Daerah menjamin kebebasan berkeyakinan dan menjalankan ibadah sehingga kerukunan antara umat Beragama dapat terjalin dengan baik. Perlindungan hak atas berkeyaninan, beragama dan beribadah terutama di Indonesia dapat ditelusuri dari Pancasila khususnya sila pertama "Ketuhanan Yang Maha Esa", menyampaikan bahwa 
Negara Kesatuan Indonesia berdasarkan nilai Ketuhanan Yang Maha Esa dan warga Indonesia harus bisa mengembangkan semangat toleransi, saling menghormati antar pemeluk keyakinan, agama dan kepercayaan yang berbedabeda atas dasar nilai universal Ketuhanan Yang Maha Esa tersebut. Atas dasar tersebut sudah menjadi tanggung jawab Kepala Daerah untuk menjaga kondusifitas Kota agar konflik tidak menjadi sebuah ancaman yang besar bagi masyarakat. Resolusi konflik dalam implementasi kebijakan mengenai objek konflik sudah dapat dijalan dengan baik dengan hasil kedaan dan situasi yang kembali kondusif namun sosialisasi kebijakan mengenai pendirian rumah ibadah harus tetap dijalankan karena jangan sampai ketidapahaman masyarakat tentang hal tersebut di manfaatkan oleh sekelompok orang untuk membuat konflik demi kepentingan pribadi.

\section{b. Menjalin Hubungan Kerjasama}

Kerjasama dapat di artikan sebagai suatu usaha bersama antara orang perorangan atau kelompok manusia untuk mencapai suatu atau beberapa tujuan bersama. Bentuk kerja sama tersebut berkembang apablia orang dapat di gerakan untuk mencapai suatu tujuan bersama dan harus ada kesadaran bahwa tujuan tersebut dikemudian hari mempunyai manfaat bagi semua Kerjasama timbul apabila orang menyadari bahwa mereka mempunyai kepentingankepentingan yang sama dan pada saat yang bersamaan mempunyai tujuan yang bermanfaat bagi semua.

Menurut hasil wawancara dengan Lurah Kebonlega mengenai adanya kerjasama antara masyrakat dengan pihak Gereja mengemukakan:

"Setelah musyawarah dan negosiasi dilakukan oleh pihak masyarakat dan panitia Gereja pada akhirnya mencapai titik damai sampai saat ini. Tidak ada lagi masyarakat yang merasa keberatan atas pendirian rumah ibadah. Bentuk terimaksih dari Panitia kepada warga RW 09 pihak Gereja memberika 1 buah ambulance, tanah wakaf, dan bantuan usaha sebesar Rp. 500.000,-. Bantuan diberikan bukan bentuk pungli atau suap karena bantuan diberikan setelah izin pendirian Gereja telah selesai."

Keterangan tersebut dibenarkan oleh hasil wawancara peneliti dengan Panitia Pembangunan Gereja, beliau mengemukakan:

"Bantuan yang diberikan oleh Panitia merupakan bentuk terimakasih dan sudah menjadi kesepakatan bersama untuk menjaga Wilayah RW 09. Berupa satu ambulance, tanah wakaf dan bantuan usaha. Besar harapan panitia agar 
bantuan tersbut dapat membantu kebutuhan di RW 09."

Resolusi konflik setelah tahap musywarah dan negosiasi disepakati terjalinlah kerjasama antara masyrakat dengan panitia pambanguna Gereja. Dengna bukti sebanyak 230 masyrakat menandatangani dan memberi keterangan bahwa masyarakat sepenuhnya sudah setuju dengan pembangunan Gereja. Bentuk terimakasih dan sesuai kesepakatan untuk tetap menjaga lingkungan RW 09 maka pihak panitia pembangunan Gereja meberikan CSR berupa satu ambulance, tanah waqaf dan bantuan untuk dana usaha bagi masyarakat yang memiliki usaha. Bantuan tersebut diberikan dua bulan setelah izin memndirikan bangunan sudah ada. Ini terbukti bahwa menjalin kerjasama antar pihak masyarakat dan panitia sudah terjalin dengan optimal.

\section{c. Terjalin Keadaan Damai}

Terjalin keadaan damai dan terus menerus merupakan tujuan akhir dari kegiatan resolusi konflik. Damai bukanlah semata-mata ketiadaan perang, tapi suatu keadaan dinamis, partisipatif, dan kondusif yang berdasar pada nilai-nilai universal di segala level keseharian yaitu keadaan damai dalam resolusi konflik berhubungan dengan keberhasilan upaya atau hasil resolusi konflik (kesepakatan, peraturan atau undang-undang) untuk menyelesaikan konflik. Hasil wawancara peneliti dengan Kepala Badan Kewaspadaan Nasional Bakesbangpol Kota Bandung beliau mengemukakan:

"Saat ini tidak ada pelaporan atau indiaksi konflik yang terjadi di Wilayah Kebonlega. Saat melakukan monitoring situasi sudah kembali damai dan tertib, tidak adanya ujuk rasa. Namun tetap perlu akan dilakukan monitoring hingga gedung tersebut sudah jadi."

Berdasarkan hasil wawancara dengan Lurah Kebonlega mengenai terjalinnya keadaan damai, beliau mengemukakan:

"Sampai saat ini dalam kehidupan masyarakat di RW 09 sudah damai tidak ada yang menolak karna menolakpun sudah ditetapkan bahwa pendirian Gereja sudah sah dan sudah ditetapkan. Namun perlu tetap melakukan pengawasan agar tidak ada lagi ujaran kebencian apalagi merusak kerukunan umat beragama."

Warga RW 09 tidak lagi merasa keberatan dengan pendirian rumah ibadah asal sesuai dengan kesepakatan bersama untuk menjaga lingkungan RW 09 dan 
tidak merugikan wara RW 09. Dari hal tersebut bahwa resolusi konflik sudah dilakukan dengan optimal dengan terbukti dari setiap tahap resolusi konflik dilakukan dengan semestinya sehingga menemukan kesepakatan yang mengahsilkan keadaan yang aman, nyaman sejahtera sesuai dengan Visi Kota Bandung sebagai Kota yang Aman, Nyaman, dan Sejahtera. Resolusi konflik pada tahap terakhir dan menjadi tujuan awal dalam meresolusi konflik yaitu terjalin keadaan yang damai dan tidak ditemukan indikasi terjadinya penolakan kembali. Panitia Gereja dapat dengan tenang membangun Gereja tanpa adanya ancaman. Namun perlu adanya pengawasan yang tetap dilakukan oleh RW 09 dan Lurah Kebonlega agar tetap pada prosedur atau kebijakan yang telah ada sehinngga situasi kondusif dapat terjalin cukup lama. Baha resolusi konflik sudah dilakukan dengn semaksimal mungkin berkat kerjasama yang solid semua pihak yang terlibat. Ini bisa menjadi contoh dalam resolusi konflik dalam pendirian rumah ibadah di wilayah lain di Kota Bandung.

\section{KESIMPULAN}

Berdasarkan analisis dari pembahasan peneliti mengenai Resolusi Konflik dalam Pendirian Rumah Ibadah Gereja Bethel Indonesia Kelurahan Kebonlega Kecamatan Bojongloa Kidul Kota Bandung, peneliti mengambil kesimpulan sebagai berikut :

\section{Peacekeeping}

a. Melakukan Pengawasan di Tempat Konflik Pengawasan ditempat konflik telah dilaksanakan dengan optimal oleh Pemrintah Kota Bandung, Kelurahan, Polsek Bojongloa Kidul, Babinkamtibmas, dan pengurus RW 09 sehingga konflik dapat segera ditangani.

b. Adanya keterlibatan Aparat Penegak Hukum

c. Keterlibatan penegak hukum atau aparat kepolisian dalam melakukan pengawasan di tempat terjadinya konflik telah dilakukan secara rutin yang berkoordinasi dengan Pemerintah Daerah, Babinkamtibams, Kelurahan Kebonlega, dan pengurus RW 09.

\section{Peacemaking}

a. Melakukan Musyawarah dan Negosiasi 
Musywarah dan negosiasi berhasil dilakukan dengan beberpa kesepakatan

b. Adanya Intervensi Pihak Ketiga

c. Intervensi pihak ketiga atau adanya keterlibatan pihak ketiga dalam penyelesaian konflik pendirian Gereja. Ini terbukti dengan adanya berita acara musyawarah yang bertempat di Aula Kecamatan Bojongloa Kidul yang dihadiri oleh Camat Bojongloa Kidul, Lurah Kebonlega, perwakilan KUA, perwakilan Polsek Bojongloa Kidul, dan Badan Kewaspadaan Nasioanal Bakesbangpol Kota Bandung Pembuatan Peraturan Mengenai Objek Konflik

d. Peraturan sudah sangat jelas mengenai pendirian rumah ibadah.

3. Peacebuilding

a. Menjalin Hubungan Kerjasama

Masyarakat tidak lagi merasa keberatan dengan adanya pendirian Gereja di RW 09 Kelurahan Kebonlega, karena masyarakat percaya bahwa tolerasni itu penting.

b. Terjalin Keadaan Damai

Warga RW 09 tidak lagi merasa keberatan dengan pendirian rumah ibadah asal sesuai dengan kesepakatan bersama untuk menjaga lingkungan RW 09 dan tidak merugikan wara RW 09.

\section{DAFTAR PUSTAKA}

\section{Buku-Buku}

Robert H. Lauer. 2001. Perspektif Tentang Perubahan Sosial. Jakarta: PT. Rineka Cipta.

Rusdiana, H.A M.M. 2015. Manajemen Konflik. Bandung. Pustaka Setia

Adon Nasrullah Jamaluddin. 2015. Agama \& Konflik Sosial Studi Kerukunan Umat Beragama, Radikalisme, Dan Konflik Antarumat Beragama. Bandung: Pustaka Setia.

Elly M. Setiadi dan Usman Kolip. 2011. Pengantar Sosiologi Pemahaman Fakta dan Gejala Permasalahan Sosial: Teori, Aplikasi, dan Pemecahannya. Jakarta: Kencana Prenada Media GrouP

Halili, Naispospos, dan Tigor Bonar. 2015. Dari Stagnasi Menjemput Harapan Baru: Kondisi Kebebasan Beragama/Berkeyakinan di Indonesia tahun 2014. Jakarta: Setara Institute- Pustaka Masyarakat Setara.

Hakim, Bashori A. 2004. Fungsi Sosial Rumah Ibadah dari Berbagai Agama: dalam Perspektif Kerukunan Umat Beragama. Jakarta: Proyek Peningkatan Pengkajian Kerukunan Hidup Umat Beragama, Puslitbang Kehidupan Beragama, Badan Litbang Agama dan Diklat Keagamaan Departemen Agama RI. 
Meleong, J.Lexy. 2007. Metode Penelitian Kualitatif. Bandung: PT Remaja Rosdakarya.

Nasdian, Fredian Tony. 2003. Pengembangan Masyarakat. Bogor: Yayaysan Obor Indonesia.

Jamaludin, Dr Adon Nasrulloh. 2015. Agama \& Konflik Sosialm Studi Kerukunan Umat Beragama, Radikalisme, dan Konflik Antarumat Beragama. Bandung: Pustaka Setia. 